\title{
Pigment Distribution and Epidermal Cell Shape in Dendrobium Species and Hybrids
}

\author{
Rasika G. Mudalige, Adelheid R. Kuehnle ${ }^{1}$, and Teresita D. Amore \\ Department of Tropical Plant and Soil Sciences, University of Hawaii at \\ Manoa, 3190 Maile Way, Honolulu, HI 96822-2279
}

\author{
Additional index words. Dendrobium, pigment distribution, epidermal cell shape, flower \\ color, petal texture, orchid, Orchidaceae
}

\begin{abstract}
Perianths of 34 Dendrobium Sw. species and hybrids were examined to elucidate the roles of pigment distribution and shape of upper epidermal cells in determining color intensity, perception, and visual texture. Color intensity was determined by the spatial localization of anthocyanin in tissue layers, i.e., in the epidermal, subepidermal, and mesophyll layers, as well as by distribution of pigmented cells within the tissue layer. Anthocyanins were confined to the epidermal layer or subepidermal layer in flowers with low color intensity, whereas they were also in several layers of mesophyll in more intensely colored flowers. Striped patterns on the perianth were due to the restriction of pigment to cells surrounding the vascular bundles. Color perception is influenced by the presence or absence of carotenoids, which when present, were distributed in all cell layers. Anthocyanins in combination with carotenoids resulted in a variety of flower colors ranging from red, maroon, bronze to brown, depending on the relative location of the two pigments. Four types of epidermal cell shapes were identified in Dendrobium flowers: flat, dome, elongated dome, and papillate. Epidermal cell shape and cell packing in the mesophyll affected the visual texture. Petals and sepals with flat cells and a tightly packed mesophyll had a glossy texture, whereas dome cells and loosely packed mesophyll contributed a velvety texture. The labella in the majority of flowers examined had a complex epidermis with more than one epidermal cell shape, predominantly papillate epidermal cells.
\end{abstract}

Key components of color in flowers and fruits of most higher plants are flavonoids (including anthocyanins), located in vacuoles, and carotenoids and chlorophylls, located in plastids (Mol et al., 1998; Strack and Wray, 1993). Flowers acquire their characteristic hue due to these pigments in combination with other chemical and physical factors. The physical factors encompass spatial localization of pigments and the optical properties of petal epidermal cells (Kay et al., 1981; Mol et al., 1998). The most extensive study to date on pigment distribution and epidermal cell shape in petals was done by Kay et al. (1981) wherein 201 species in 61 families were surveyed. The majority ( 85 out of 97 species) of flowers surveyed have anthocyanins confined to the epidermis and the majority of epidermal cells have their otherwise flat outer walls raised into a dome or a conical shape (Christensen and Hansen, 1988; Kay et al., 1981). These physical factors influence the role of the plant epidermis in pollinator attraction and in our perception of flower color and visual texture (Glover, 2000; Glover and Martin, 2000; Gorton and Vogelmann 1996; Noda et al., 1994). An understanding of the latter is

Received for publication 6 May 2002. Accepted for publication 6 Oct. 2002. This paper is a portion of a dissertation submitted by R.G.M. This research was supported by the U.S. Dept. of Agriculture under CSREES Special grant Agreement No. 96-341352480, managed by the Pacific Basin Administrative group (PBAG).

${ }^{1}$ To whom reprint requests should be addressed E-mail address: heidi@hawaii.edu. valuable to flower breeding programs. tion and epidermal cell shape are limited to a few species. Matsui $(1990,1992)$ showed in Cattley Lindl. and allied genera that the spatial localization of anthocyanins and carotenoids affected perception of color intensity and quality, while the height/width ratio of epidermal cells determined the visual texture. In Dendrobium, little is known regarding the histology of flower pigmentation. Flower epidermal cell shapes are reported only for the labella of $D$. phalaenopsis Fitzg., D. superbiens Fitzg., and D. discolor Lindl. (Vajrabhaya and Vajrabhaya, 1984). The objectives of this study were to describe distribution patterns of pigments in the Dendrobium perianth tissues, to identify epidermal cell shapes in Dendrobium flowers, and to relate these factors to the color and texture perceived.

\section{Materials and Methods}

Plant material. Inflorescences of 34 Dendrobium species and hybrids (Table 1) were selected to represent a range of flower colors and visual textures. Six different color groups were examined: whites, pale/pastel colors, lavender/purple, striped, blue, and purple/yellow combinations. Two visual texture groups were selected: glossy and velvety. Detailed RHS (Royal Horticulture Society, London, England) color descriptions of most flowers can be found in Kamemoto et al. (1987) and Kuehnle et al. (1997). Inflorescences were harvested from plants maintained
In Orchidaceae, data on pigment distribu- at the orchid greenhouse facility of the Univ. of Hawaii at Manoa and submerged in tap water for $10-15 \mathrm{~min}$. Stems were recut under water, bases were left immersed in water, and flowers were analyzed on the same day whenever possible or within $2 \mathrm{~d}$.

Preparation oftissue sections and analysis. A simple new method was used to make transverse sections. Perianth parts were separated and immersed in a series of polyethylene glycol (PEG) solutions (M.W. 8000, Sigma Chemical Co., St. Louis) ranging from $0.1 \%$ to $0.5 \%(\mathrm{w} / \mathrm{v})$ prior to sectioning. The solution with an osmotic potential closest to that of the perianth cells was determined by observing the amount of plasmolysis in the intact cells of the sections. Our observations indicated that $0.25 \%$ PEG solution had an osmotic potential close to that of perianth cells. For flowers with large and abundant intercellular air spaces in the mesophyll, perianth parts were first infiltrated with $0.25 \%$ PEG under building vacuum $(\approx 600$ $\mathrm{mm} \mathrm{Hg}$ ). Perianth parts sank to the bottom of the solution after successful infiltration. Vacuum infiltration was required for all flowers with loosely packed mesophyll, i.e., with large and numerous air spaces. It improved the sectioning substantially since replacement of air with PEG solution resulted in firmer tissues (hydrostatic pressure) and eliminated air bubbles trapped inside sections that otherwise hindered analysis. In contrast, Dendrobium petals with glossy texture (Table 2) were easier to section and did not need vacuum infiltration. Transverse sections $(0.1-0.2 \mathrm{~mm}, 2-3$ cell layers thick) from the middle of the petal, sepal, and the labellum of each flower were then taken using a sharp razor blade, mounted in $0.25 \%$ PEG solution, and examined using a Nikon Microphot SA microscope with Nikon SX 35A camera attachment. Pigment location (vacuole or plastid), color, distribution within the different cell layers, and adaxial epidermal cell shapes were noted for each sample. Sections found to have both anthocyanins and carotenoids were sealed by applying a layer of nail varnish around the coverslip, and kept overnight until the purple color disappeared, to visualize the distribution of carotenoids without interference from anthocyanins.

\section{Results}

Spatial localization of anthocyanins. As expected, white flowers lacked any colored cells in their tissues (Fig. 1 A and B). Anthocyanins were confined to a single layer of cells, either to the epidermal or to the subepidermal layer, in petals and sepals of all light colored flowers grouped under the pale/pastel and white/purple mixed categories (Table 1 and Fig. 1C-F). In contrast, anthocyanins were present either in two cell layers (epidermal and subepidermal layer), or in many cell layers of epidermis and mesophyll, in all more intensely colored flowers as grouped in the lavender/purple (Table 1 and Fig. 1G-J) and the blue categories. Multiple layering of the colored cells likely increased the pathlength of light and thereby increased light absorption thus darkening the flower color. Intensely colored 
spherical pigment bodies were seen within the pigmented vacuole of some examples in the blue category ( $D$. Betty Goto).

Color intensity also was determined by distribution of pigment within a single tissue. For example, very light colored $D$. Jaquelyn Thomas cultivars 'Uniwai Blush', Y166-1 (Fig. $1 \mathrm{C}$ and $\mathrm{D}$ ), and $D$. Neo-Hawaii had only a few colored cells in the cell layer beneath the adaxial epidermis (sub-epidermal layer), whereas the 'darker' pastel $D$. Icy Pink 'Sakura' had most of the sub-epidermal layer consisting of colored cells. Labella of pale/pastel and purple-white flowers had darker coloration than the corresponding petals and sepals and contained anthocyanin in both the epidermal and subepidermal cells (Fig. 1 E and F). A majority of the flowers (19/34) across all phenotypic classes shared a similar pigment distribution pattern in petals and sepals that differed from the labella (Table 1).

Flowers with striped patterns. Flowers with striped patterns generally had pigmentation confined to the epidermal or mesophyll cells close to the vascular bundles (Fig. 2). Anthocyanin-containing cells were restricted to the mesophyll surrounding the vascular bundles in $D$. Hirota $\times D$. Candy Stripes (Fig. $2 \mathrm{~A}$ and $B$ ), whereas they were confined to parts of the adaxial epidermis directly above vascular bundles in the labellum of $D$. canaliculatum $\mathrm{x} D$. taurinum (Fig. $2 \mathrm{C}$ and $\mathrm{D})$. In addition, carotenoids in the striped $D$. bullenianum (Fig. $2 \mathrm{E}$ and $\mathrm{F}$ ) were found in the cytoplasm in unique reticulate structures, which are presently being investigated for detailed ultrastructure. One exception to stripes mimicking the venation pattern of the perianth is D. spectabile, where the striped pattern of the labellum was independent of venation.

Distribution of pigments in purple/yellow combinations. Flowers in this category were bronze, bronze with purple labellum, brown, yellow with brown markings, and yellow with purple labellum. Carotenoids were present throughout the epidermal, subepidermal, and mesophyll layers in all color groups. In contrast, anthocyanin localization varied considerably within the purple/yellow category: only in the epidermis, as in labellum of $D$. Sri Siam and (D. Jaquelyn Thomas $\times$ D. Field King) $\times$ D. May Neal 'Srisopon' (Fig. 3 A and B) or to the mesophyll as in petals and sepals of $D$. gouldii (Fig. $3 \mathrm{C}$ and D). Anthocyanins were also located in the epidermis and subepidermal layer (Fig. $3 \mathrm{E}$ and $\mathrm{F}$ ) or across all cell layers (Fig. $3 \mathrm{G}$ and $\mathrm{H}$ ).

Cell shapes of the upper epidermis. Four types of epidermal cell shapes were found in Dendrobium flowers: flat, dome (height/width $<1.2$ ), elongated dome (height/width $>1.2$ ) and papillate (Fig. 4; Table 2). Of all the flowers we examined, those belonging to section Spatulata and their hybrids $(D$. gouldii, D. lasianthera, $D$. canaliculatum $\times$ D. taurinum, $D$. Autumn Lace and $D$. Betty Goto) had flat epidermal cells (Fig. 4A and Table 2) in the petals and sepals. Cuticles of glossy textured flowers were twice as thick as those of velvety textured flowers (Fig. 4). All $D$. Jaquelyn Thomas-type hybrids (section Spatulata $\mathrm{x}$ section Phalaenanthe) such as 'Uniwai Blush', 'Uniwai Prince',

Table 1. Pigment distribution in the epidermal, subepidermal, and mesophyll cells of the perianth of Dendrobium

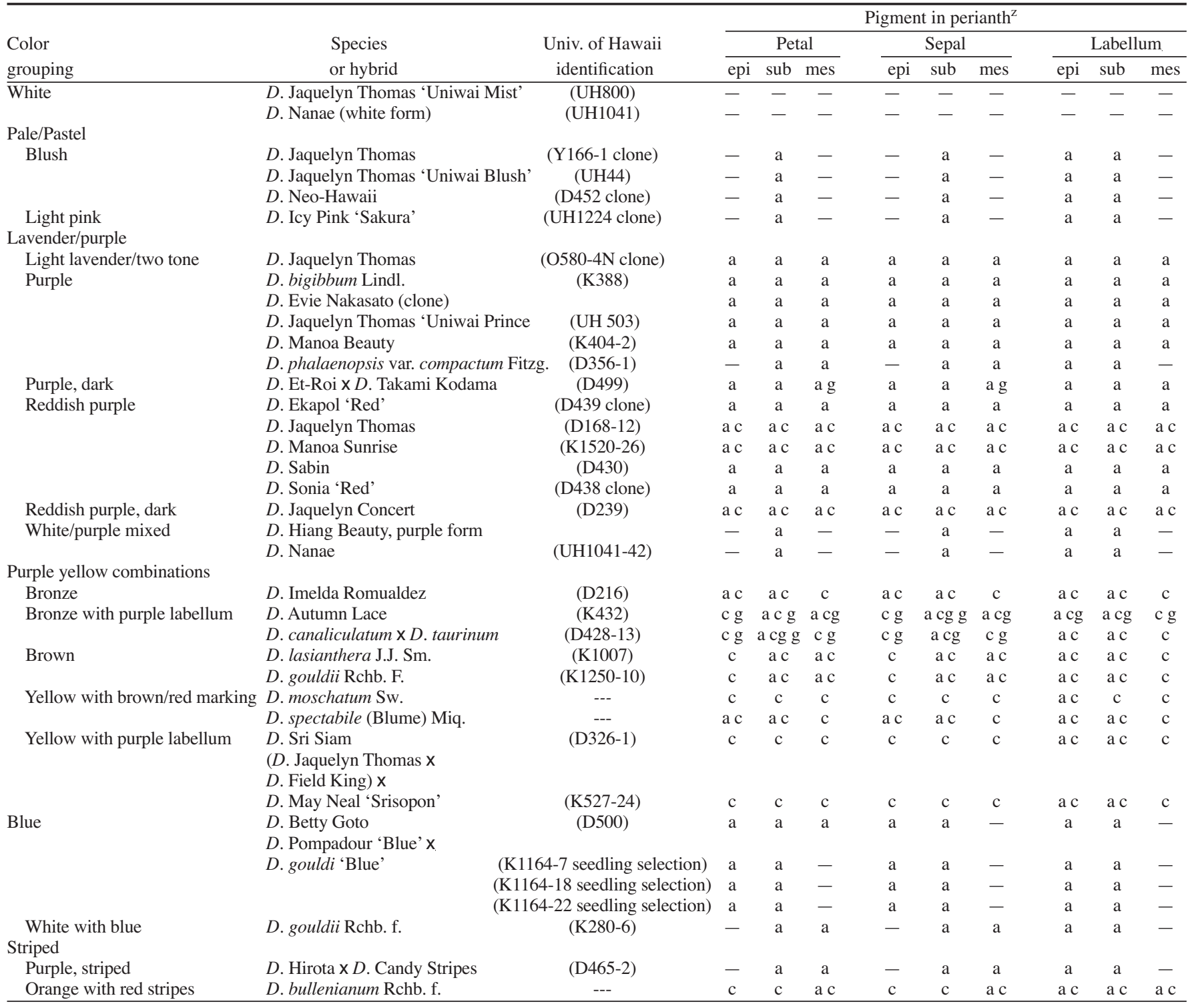

${ }^{2}$ Abbreviations: epi $=$ epidermal layer, sub $=$ subepidermal layer, mes $=$ mesophyll; $\mathrm{a}=$ anthocyanin, $\mathrm{c}=$ carotenoids, $\mathrm{g}=$ chlorophyll, $-=$ lack of pigment. 


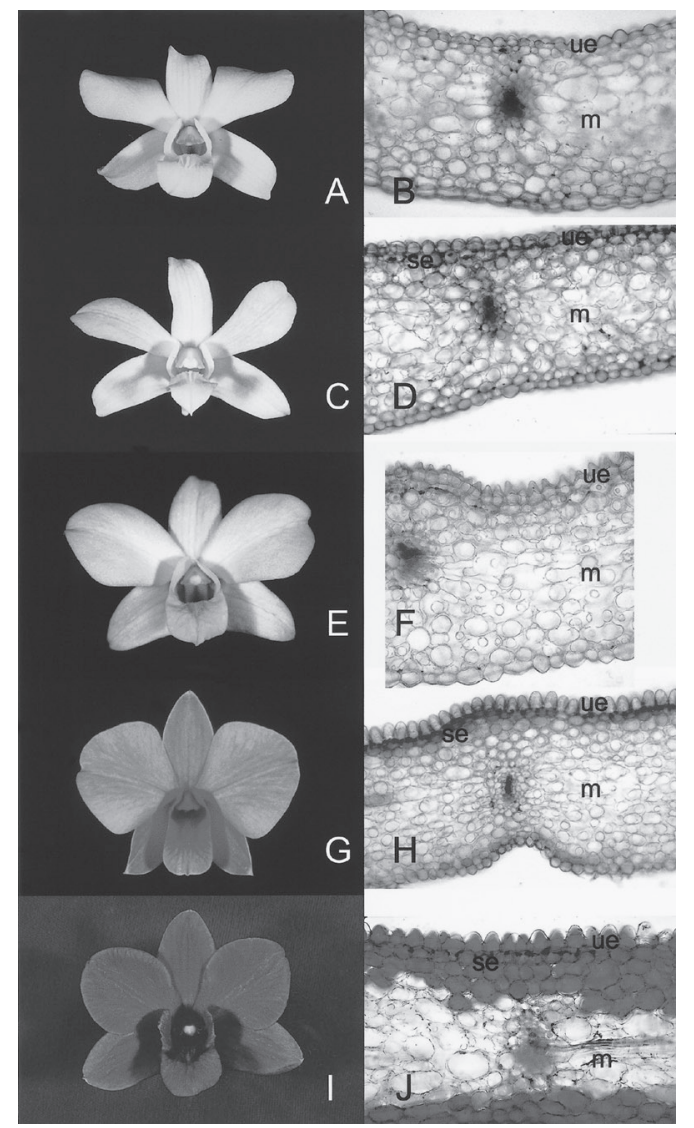

Fig. 1. Front view and transverse sections (t.s.) of the perianths of Dendrobium flowers showing the location of pigmented cells. (A) and (B) D. Nanae (white form) with t.s. of petal $\times 100$. (C) and (D) $D$. Jaquelyn Thomas Y166-1 with t.s. of petal $\times 100$. $(\mathbf{E})$ and $(\mathbf{F}) D$. Icy Pink 'Sakura' with t.s. of labellum $\times 100$. $(\mathbf{G})$ and $(\mathbf{H})$ D. phalaenopsis var. compactum with t.s. of petal $\times 100$. (I) and $(\mathbf{J}) D$. Et-Roi $\mathbf{X} D$. Takami Kodama with t.s. of petal $\times 100$. ue $=$ epidermis, se $=$ sub-epidermal layer, $\mathrm{m}=$ mesophyll.

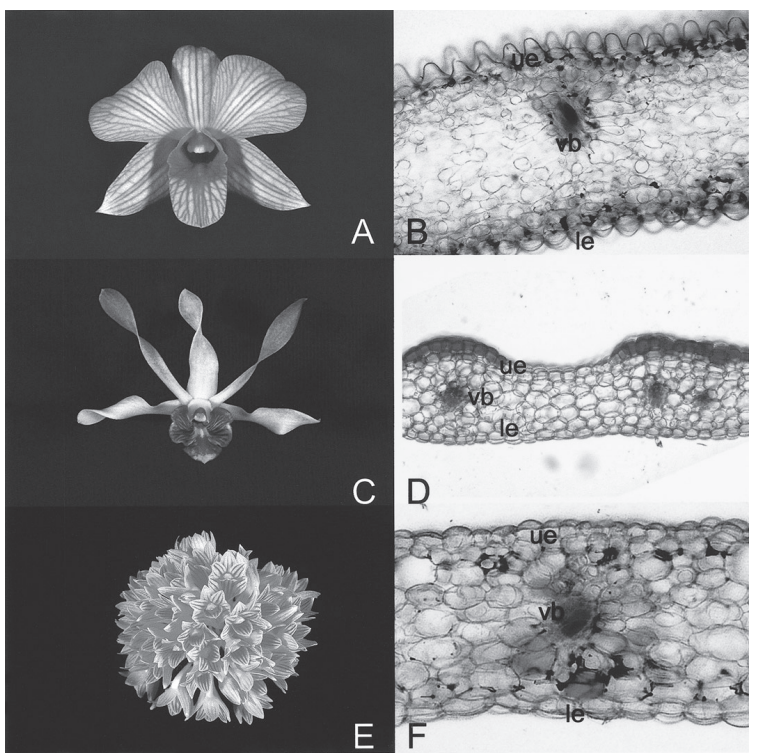

Fig. 2. Localization of pigmented cells around the vascular bundle in Dendrobium flowers with striped patterns. (A) and (B) D. Hirota $\mathbf{X} D$. Candy Stripe, with petal t.s. $\times 100$. (C) and $(\mathbf{D}) D$. canaliculatum $\times$ D. taurinum, with labellum t.s. $\times 100$. (E) and (F) D. bullenianum, with petal t.s. $\times 100$. ue $=$ upper epidermis, $\mathrm{vb}=$ vascular bundle, $\mathrm{m}=$ mesophyll.

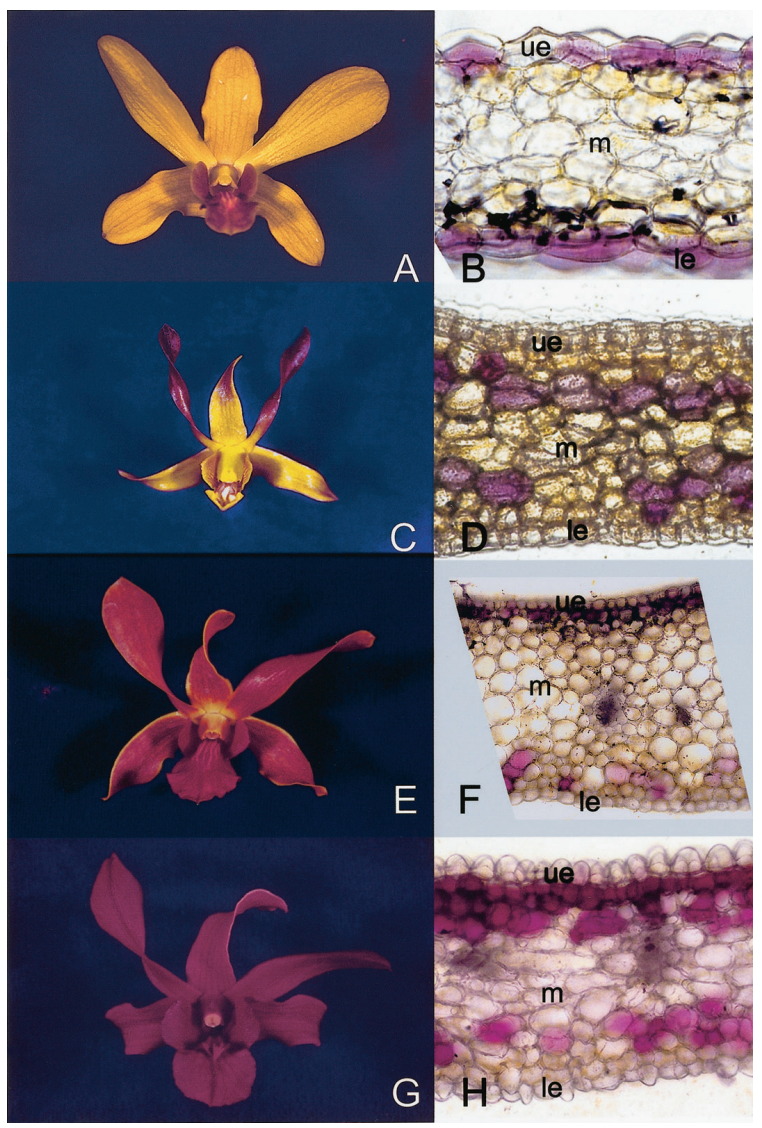

Fig. 3. Effect of yellow carotenoids in combination with anthocyanins on perception of flower color in Dendrobium flowers. Front view of flowers and transverse sections of the perianth showing the perceived color and the relative location of yellow carotenoids and purple anthocyanins in perianth tissues. (A) and (B) yellow flower of ( $D$. Jaquelyn Thomas $X D$. Field King) $\mathrm{X} D$. May Neal 'Srisopon' showing purple labellum and its section $\times 160$. (C) and (D) brown flower of D. gouldii, with petal section $\times 100$. (E) and (F) bronze colored $D$. Imelda Romualdez, with petal section $\times 160$. (G) and (H) reddish purple $D$. Jaquelyn Concert, with sepal section $\times 100$. ue $=$ upper epidermis, $\mathrm{m}=$ mesophyll, le $=$ lower epidermis.

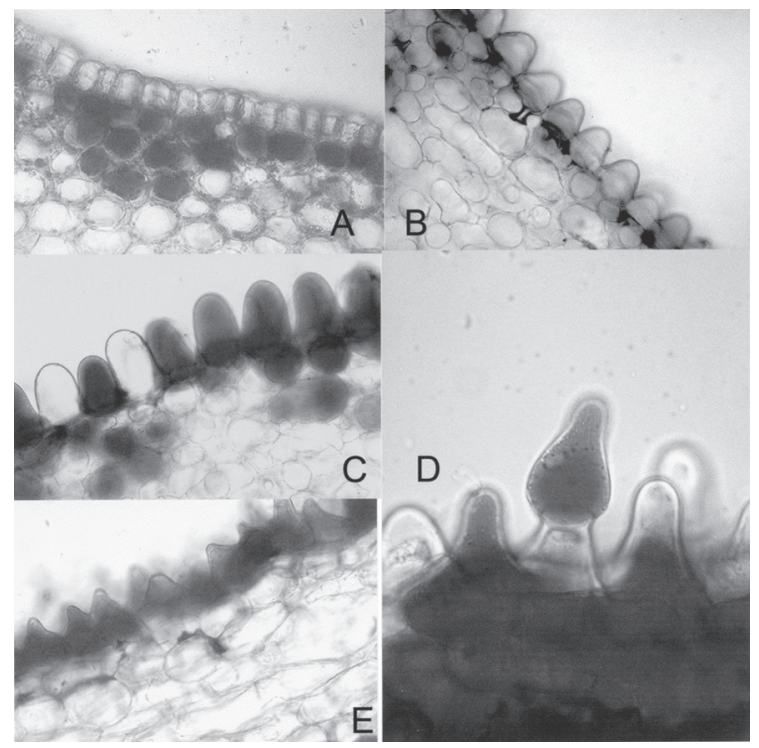

Fig. 4. Various shapes of upper epidermal cells found in the perianth of Dendrobium. (A) flat epidermal cells of D. lasianthera (Section Spatulata) $\times 400$. (B) domed cells of $D$. Jacquelyn Thomas O580-4N (Section Spatulata $\mathrm{X}$ Section Phalaenanthe $\times 200$. (C) elongated dome shape of D. biggibum (Section Phalaenanthe $\times 200$. (D) epidermal hair on the labellum of $D$. Sabin $\times 400$. (E) papillate cells of $D$. Betty goto (labellum section) $\times 200$. 
O580-4N, D168-12, 'Uniwai Mist', $D$. NeoHawaii, D. Manoa Sunrise, and $D$. Jaquelyn Concert had dome-shaped epidermal cells (Fig. 4B and Table 2) in their petals and sepals. In addition, $D$. Hiang Beauty, $D$. Icy Pink 'Sakura', D. Nanae (white and purple-white forms), and $D$. Evie Nakasato also had domeshaped cells in the petals and sepals (Table 2). Dendrobium phalaenopsis var. compactum and D. bigibbum (section Phalaenanthe) had elongated dome-shaped epidermal cells (Fig. 4C and Table 2). Height of epidermal cells appears to be more uniform in petals compared to sepals. Height/width ratios of the sepal epidermal cells varied considerably $(0.8-1.2)$, which made it difficult to differentiate between dome and the elongated dome shapes in some flowers. An epidermal hair comprised of two cells, a cylindrical base, and a conical head, was seen on the following: $D$. Sonia 'Red', $D$. Ekapol 'Red', D. Sabin (Fig. 4D), D. Et-Roi x $D$. Takami Kodama and $D$. Manoa Beauty (Table 2 ), while $D$. moschatum was the only exception with multicellular hairs on its labellum.

Labella in Dendrobium appear more complex than petals and sepals in terms of epidermal cell shape. Various shapes of epidermal cells can be observed in a single labellum. Epidermal cells toward the distal end of the labellum were often similar to those found on the petals (Table 2). When sectioned across the ridges or keels, papillate cells were the most common cell type found in most flowers examined (Fig. 4E and Table 2). Papillate cells of labella also had visible surface striations on their cuticles similar to those observed by Vajrabhaya and Vajrabhaya (1984).

\section{Discussion}

Distribution of anthocyanins appeared to be much more variable in Dendrobium compared to other plant genera. Kay et al. (1981) found that the anthocyanins were confined to the epidermis in the petals of a majority of species surveyed ( 85 out of 97) while they were confined to the mesophyll only in a few species of Boraginaceae. A few species (7/97) had anthocyanins in epidermis as well as mesophyll. In Dendrobium, anthocyanin distribution varied considerably within the genus. It can be confined to the epidermis or mesophyll in some species/hybrids while it is distributed throughout all cell layers in others. However, pigment distribution pattern in Dendrobium is consistent with some of the genera previously examined in the Orchidaceae. In most Cattleya species anthocyanin was confined to the meso-

Table 2. Shapes of the adaxial epidermal cells of the perianth of Dendrobium.

\begin{tabular}{|c|c|c|c|c|}
\hline \multirow{2}{*}{$\begin{array}{l}\text { Species } \\
\text { or hybrid }\end{array}$} & \multirow{2}{*}{$\begin{array}{l}\text { Univ. of Hawaii } \\
\text { identification }\end{array}$} & \multicolumn{3}{|c|}{ Upper epidermal cell shape $^{z}$} \\
\hline & & Petal & Sepal & Labellum \\
\hline \multicolumn{5}{|c|}{ Glossy texture } \\
\hline D. Autumn Lace & $(\mathrm{K} 432)$ & f & $\mathrm{f}$ & $\mathrm{f}$ \\
\hline$D$. Betty Goto & (D500) & $\mathrm{f}$ & $\mathrm{f}$ & $\mathrm{p}$ \\
\hline D. canaliculatum $\times$ D. taurinum & (K428-13) & $\mathrm{f}$ & $\mathrm{f}$ & $\mathrm{f}$ \\
\hline D. gouldii blue phenotype & $(\mathrm{K} 280-6)$ & $\mathrm{f}$ & $\mathrm{f}$ & $\mathrm{f}$ \\
\hline D. gouldii brown phenotype & (K1250-10) & $\mathrm{f}$ & $\mathrm{f}$ & $\mathrm{f}$ \\
\hline D. Imelda Romualdez & (D216) & $\mathrm{f}$ & $\mathrm{f}$ & $\mathrm{p}$ \\
\hline (D. Jaquelyn Thomas $\mathrm{x} D$. Field King) & & & & \\
\hline x D. May Neal 'Srisopon' & $(\mathrm{K} 527-24)$ & $\mathrm{f}$ & $\mathrm{f}$ & $\mathrm{f}, \mathrm{p}$ \\
\hline D. lasianthera & $(\mathrm{K} 1007)$ & $\mathrm{f}$ & $\mathrm{f}$ & f \\
\hline D. moschatum & - & $\mathrm{f}$ & $\mathrm{f}$ & $\mathrm{f}, \mathrm{p}, \mathrm{h}^{\mathrm{y}}$ \\
\hline D. Sri Siam & (D326-1) & f & f & $\mathrm{f}, \mathrm{p}$ \\
\hline \multicolumn{5}{|c|}{ Velvety texture } \\
\hline D. bigibbum & $(\mathrm{K} 388)$ & $\mathrm{e}$ & $\mathrm{e}$ & $\mathrm{e}, \mathrm{p}$ \\
\hline D. bullenianum & & $\mathrm{f}, \mathrm{d}$ & $f, d$ & $f, d$ \\
\hline D. Ekapol 'Red' & (D439) & $\mathrm{e}$ & $\mathrm{e}$ & $\mathrm{p}, \mathrm{h}$ \\
\hline D. Evie Nakasato & & d & d & $\mathrm{p}$ \\
\hline D. Et-Roi x D. Takami Kodama & (D499) & e & d & $e, p, h$ \\
\hline$D$. Hiang Beauty & & d & d & $\mathrm{d}, \mathrm{p}$ \\
\hline$D$. Hirota $x$ D. Candy Stripes & (D465-2) & $\mathrm{e}$ & $e, d$ & $e, p$ \\
\hline D. Icy Pink 'Sakura' & (K 1224) & d & $\mathrm{d}$ & $\mathrm{d}, \mathrm{p}$ \\
\hline$D$. Jaquelyn Concert & (D239) & d & d & $\mathrm{d}, \mathrm{p}$ \\
\hline$D$. Jaquelyn Thomas & $(\mathrm{O} 580-4 \mathrm{~N})$ & d & d & $\mathrm{f}, \mathrm{d}, \mathrm{p}$ \\
\hline$D$. Jaquelyn Thomas & $(Y 166-1)$ & d & d & $\mathrm{f}, \mathrm{d}, \mathrm{p}$ \\
\hline$D$. Jaquelyn Thomas & (D168-12) & d & d & $\mathrm{f}, \mathrm{d}, \mathrm{p}$ \\
\hline D. Jaquelyn Thomas 'Uniwai Blush' & (UH44) & d & d & $\mathrm{f}, \mathrm{p}$ \\
\hline D. Jaquelyn Thomas 'Uniwai Mist' & (UH800) & d & d & $\mathrm{d}, \mathrm{p}$ \\
\hline D. Jaquelyn Thomas 'Uniwai Prince' & (UH503) & $\mathrm{d}$ & d & $\mathrm{f}, \mathrm{d}, \mathrm{p}$ \\
\hline D. Manoa Beauty & $(\mathrm{K} 404-2)$ & e & $\mathrm{e}$ & $\mathrm{e}, \mathrm{p}, \mathrm{h}$ \\
\hline$D$. Nanae (purple \& white forms) & (UH1041) & d & d & $\mathrm{d}, \mathrm{p}$ \\
\hline D. Neo-Hawaii & (D452) & d & $\mathrm{d}$ & $\mathrm{f}, \mathrm{p}$ \\
\hline D. phalaenopsis var. compactum & $(\mathrm{D} 356-1)$ & $\mathrm{e}$ & $e, d$ & $e, p$ \\
\hline \multirow[t]{3}{*}{ D. Pompadour 'Blue' x D. gouldii 'Blue' } & (K 1164-7 seedling selection) & f, d & $\mathrm{f}, \mathrm{d}$ & f, d \\
\hline & (K 1164-18 seedling selection) & $\mathrm{d}$ & $\mathrm{d}$ & $\mathrm{f}, \mathrm{d}$ \\
\hline & (K 1164-22 seedling selection) & d & $\mathrm{f}, \mathrm{d}$ & $\mathrm{f}, \mathrm{d}$ \\
\hline D. Sabin & $(\mathrm{D} 430)$ & $\mathrm{e}$ & $\mathrm{e}$ & $\mathrm{e}, \mathrm{p}, \mathrm{h}$ \\
\hline D. Sonia 'Red' & (D438) & $e, d$ & $\mathrm{~d}$ & $\mathrm{e}, \mathrm{p}, \mathrm{h}$ \\
\hline D. spectabile & - & $\mathrm{d}, \mathrm{e}$ & $\mathrm{f}, \mathrm{d}$ & d,e \\
\hline D. Manoa Sunrise & $(\mathrm{K} 1520-26)$ & $\mathrm{d}$ & $\mathrm{d}$ & $\mathrm{f}, \mathrm{d}, \mathrm{p}$ \\
\hline
\end{tabular}

${ }^{\mathrm{z}}$ Abbreviations: $\mathrm{f}=$ flat, $\mathrm{d}=$ dome, $\mathrm{e}=$ elongated dome, $\mathrm{p}=$ papillate, $\mathrm{h}=$ epidermal hair.

${ }^{\mathrm{y}}$ Multicellular hair. phyll, while Cattleya with splashed petals, and some species of Laelia with intensely colored flowers had anthocyanin in the epidermis as well as mesophyll (Matsui, 1990). Anthocyanin is confined to the epidermis in Sophronitis and Sophronitella species (Matsui, 1990). This unusual variation of pigment distribution patterns in orchids might be a result of an extremely large number of man-made interspecific and intergeneric hybrids.

Combinations of yellow carotenoids and purple anthocyanins result in perceived flower colors of brown, bronze, red, or wine (Griesbach, 1984; Vogelpoel, 1990). Griesbach (1984) attributed the differences in color perception to the differences in relative concentrations of yellow and purple pigments. According to this explanation, high ratios of yellow carotenoid/purple anthocyanin give a brown color and the opposite gives red colors, while equal concentration of the two gives a bronze color to the flowers. Our observations indicate that this explanation might be too simplistic for Dendrobium, for which the accumulated purple pigment is predominantly cyanidin glycosides (Kuehnle et al., 1997). The relative location of yellow and purple pigments may be as important as relative concentration in determining flower color. A good example of this is found in D. bullenianum, where red striping resulted from the combination of orange carotenoids with mesophyll-restricted purple anthocyanins. This phenomenon has been observed in other orchids such as Laelia milleri Blumensch. ex Pabst, Sophronitis coccinea (Lindl.) Rchb. f., and Broughtonia sanguinea (Sw.) R. Br., in which red color was also ascribed to the coexistence of carotenoids and anthocyanins (Matsui, 1990). This emphasizes the fact that the relative location of the two pigments is critically important in determining the shade of color.

A survey of epidermal patterns in the Angiosperms revealed two main types: tabular (flat) and papillose (Christensen and Hansen, 1998). In papillose type, the outer epidermal cell wall is raised above the epidermis into a conical, dome or papillate shape. Papillose petal surfaces are predominant among insect pollinated flowers (Christensen and Hansen, 1998). Shape and size of the epidermal cells, especially the ratio of height/width, is known to affect flower texture (Matsui, 1990). In Cattleya, glossy flowers have square-shaped epidermal cells, whereas velvety textured petals have 'deltate' epidermal cells with higher height/width ratios. Apparently in Dendrobium, both the epidermal cell shape and the nature of the aerenchymatous layer (mesophyll layer) influence the visual texture of flowers. Square cells with a thicker smooth cuticle and tightly packed mesophyll with few air spaces gave a glossy texture to the perianth, while domed cells with a thin cuticle and loosely packed mesophyll with large and numerous air spaces produced a velvety texture. Papillate cells seem to be common in a number of orchids and occur in Anacamptis pyramidalis (L.), Dactylorhiza fuchsii (Druce) Soó, (Kay et al., 1981), and many species of Cattleya and Laelia (Matsui, 1990). The preponderance of 
Dendrobium hybrids containing velvety textured flowers suggests that their dome-shaped cells are perhaps more attractive to the human eye because of the enhanced absorption of light by dome shaped cells.

Both papillate and dome-shaped cells absorb light over a greater part of their surfaces when compared to flat outer surfaces of square epidermal cells. In addition, surface striations perhaps function as an additional light-trapping device by reducing the surface reflection while smooth unstriated cuticles contributed toward strong surface reflections as suggested by Kay et al. (1981). Endress (1994) stated that intercellular spaces in the mesophyll influence the light reflection in addition to organ surface structures. Our observation on the influence of epidermal cell shape and mesophyll packing upon visual texture is confirmed by these explanations. Christensen and Hansen (1998) also revealed that the shape of papillae in a single petal can vary with more distinct papillae toward the distal end and less pronounced papillose cells toward the proximal end. The authors speculate such zonation can act as guides to the insect. Our data on labellum showed such differences in epidermal cell shape and reinforced the presumed function of the labellum as a specialized petal for insect landing and guidance. Quantitative data on floral flavonoids in Dendrobium showed that the labella contained two to four times more anthocyanins than the sepals on a fresh weight basis (Kuehnle et al., 1997). Presence of papillate cells, surface striations, the different pigment distribution patterns and higher pigment quantities, contribute to the darker color of labella seen in many flowers when compared to the color of other perianth parts.

Many chemical factors, such as type of pigment, their combinations, vacuolar $\mathrm{pH}$, and co-pigments, affect flower color. The types of flavonoids and carotenoids found in Dendrobium species and hybrids are already documented (Kuehnle et al., 1997; Thammasiri et al., 1986). This study complements the earlier work by revealing the physical factors (spatial localization of pigments, epidermal cell shape) and their effects on color perception. Since methodology for successful genetic transformation of Dendrobium is available (Nan and Kuehnle, 1995), understanding of the detailed spatial distribution of pigments will facilitate directed engineering of flower colors by permitting more sophisticated approaches in selection of appropriate target phenotypes and tissues for the expression of pigment-modifying genes. For example, a petal-specific epidermal promoter will be appropriate in color manipulation of pastel/pale flowers, while a constitutive promoter is more appropriate for the dark purple phenotypes. Isolation of colormodifying genes from Dendrobium flowers and the study of spatial and temporal regulation of these genes will bring important breakthroughs for development of novel phenotypes, while further research on inheritance of distribution pattern and epidermal cell shapes will benefit classical breeding programs.

\section{Literature Cited}

Christensen, K.I. and H.V. Hansen. 1998. SEMstudies of epidermal patterns of petals in the angiosperms. Opera Botanica 135:5-86.

Endress, P.K. 1994. Pollinator attraction, p. 174. In: P.K. Endress (ed.). Diversity and evolutionary biology of tropical flowers. Cambridge Univ. Press, Cambridge, U.K.

Glover, B.J. 2000. Differentiation in plant epidermal cells. J. Expt. Bot. 51:497-505.

Glover, B.J. and C. Martin. 1998. The role of petal cell shape and pigmentation in pollination success in Antirrinum majus. Hered. 80:778-784.

Gorton, H.J. and T.C. Vogelmann. 1996. Effects of epidermal cell shape and pigmentation on optical properties of Antirrhinum petals at visible and ultraviolet wavelengths. Plant Physiol. 112:879-888.

Griesbach, R.J. 1984. Effects of carotenoid and anthocyanin combinations on flower colour. J. Hered. 75:145-147.

Kamemoto, H., K. Thammasiri, M. Marutani, and S. Kobayashi. 1987. Polyploidy in cultivars of yellow Dendrobiums. J. Orchid Soc. India 1
$(1,2): 7-18$.

Kay, Q.O.N., H.S. Daoud, and C.H. Stirton. 1981. Pigment distribution, light reflection and cell structure in petals. Bot. J. Linn. Soc. 83: 57-84.

Kuehnle, A.R., D.H. Lewis, K.R. Markham, K.A. Mitchell, K.M. Davies, and B.R. Jordan. 1997. Floral flavonoids and $\mathrm{pH}$ in Dendrobium orchid species and hybrids. Euphytica 95:187-194.

Matsui, S. 1990. Flower pigment distribution in perianth of Cattleya and allied genera, p. 169-172. In: T. Kimura, S. Ichihashi, and H. Nagata (eds.). Proc. of the Nagoya Intl. Orchid Show ' 90 . The organizing committee of NIOS '90, Nagoya, Japan.

Matsui, S. 1992. Inheritance of distribution patterns of flower pigment and shape of its epidermal cells in Cattleya and allied genera, p. 117-122. In: S. Ichihashi, and H. Nagata (eds.). Proc. of the Nagoya Intl. Orchid Show '92. The organizing committee of NIOS '92, Nagoya, Japan.

Mol, J., E. Grotewold, and R. Koes. 1998. How genes paint flowers and seeds. Trends in Plant Sci. 3:212-217.

Nan, G.L. and A.R. Kuehnle. 1995. Genetic transformation in Dendrobium (orchid). p. 149-160. In: Y.P.S. Bajaj (ed.). Biotechnology in agriculture and forestry. Vol 34. Plant protoplasts and genetic engineering VI. Springer Verlag, N.Y.

Noda, K., B.J. Glover, P. Linstead, and C. Martin. 1994. Flower colour intensity depends on specialized cell shape controlled by a Myb-related transcription factor. Nature 369:661-664.

Strack, D. and V. Wray. 1993. The anthocyanins, p. 1-22. In: J.B. Harbourne (ed.). The flavonoids: Advances in research since 1986. Chapman \& Hall, London, U.K.

Thammasiri, K., C.S. Tang, H.Y. Yamamoto, and H. Kamemoto. 1986. Carotenoids and chlorophylls in yellow-flowered Dendrobium species. Lindleyana 1:215-218.

Vajrabhaya, M. and T. Vajrabhaya. 1984. A study of the orchid epidermis using the electron microscope, p. 335-342. In: Proc. 11th World Orchid Conf. Intl. Press Co. (Pte.) Ltd., Singapore.

Vogelpoel,L. 1990. Flower colour-An appreciation. Orchid Dig. 55:82-87.

Wagner, G.J. 1982. Cellular and subcellular localization in plant metabolism, p. 1-45. In: L.L. Greasy and G. Hrazdina (eds.). Recent advances in phytochemistry. Vol 16. Plenum Press, N.Y. 